Gazi University
Journal of Science
$\mathrm{http}: / /$ dergipark.gov.tr/gujs

\title{
Thermodynamic Analysis of Industrial Cooling Systems with the Usage of Different Types of Evaporators: Experimental Study
}

\author{
Suleyman ERTEN ${ }^{1}$ (D) , Meltem KOSAN ${ }^{2, *}$ (D) Furkan ISGEN $^{1}$ (D) Esra DEMIRCI $^{(10)}$, Mustafa AKTAS $^{3}$ \\ ${ }^{I}$ Nurdil Technical Cooling, 06500, Ankara, Turkey \\ ${ }^{2}$ Kahramanmaras Istiklal University, 46100, Kahramanmaras, Turkey \\ ${ }^{3}$ Gazi University, Department of Energy Systems Engineering, 06500, Ankara, Turkey
}

Highlights

- 1/2" smooth tube and 3/8" grooved tube types evaporators are designed for industrial refrigerators.

- Theoretical and experimental analysis and comparison of smooth and grooved tube evaporators.

- The system COP value is 2.807 , while it is calculated as 3.013 for the second system.

- The grooved tube evaporator has better cooling performance compared to the smooth tube evaporator.

Article Info

Received:01 Sep 2020

Accepted:09 Jan 2021

\section{Keywords}

Cooling

Evaporator

Energy efficiency

Hydrophilic coating

\begin{abstract}
Energy efficiency and the amount of refrigerant in heat exchangers used in cooling systems has recently been an important research subject. In this study, in order to compare and analyze different types of evaporators, industrial refrigerators were designed and in this context, test setups in accordance with TS EN ISO 23953-2 standard were produced. R290 (propane) was used as the refrigerant in the designed system. During the experiment, temperature-pressure measurements were taken at a certain point in the cooling system equipment of the products, which were cooled every minute, and test data were recorded. As a result of the data obtained from the experimental results, while the temperature difference of the air entering and leaving the evaporators was $6.797^{\circ} \mathrm{C}$ in the first system using $1 / 2$ " tube diameter evaporator, it was calculated as $7.052{ }^{\circ} \mathrm{C}$ in the corrugated and hydrophilic coated second system using $3 / 8$ " tube diameter. In the experimental setups, the energy consumed in the first and second systems and the masses of R-290 refrigerant were measured as $24.64 \mathrm{kWh}, 23.39 \mathrm{kWh}$ and 700 grams, 430 grams, respectively. Consequently, it was calculated that the second system was $5.073 \%$ and $38.57 \%$ more efficient in terms of energy efficiency and the refrigerant mass used. Coefficient of performance values for the first and second systems were found as 2.807 and 3.013, respectively.
\end{abstract}

\section{INTRODUCTION}

At present, it is known that aluminum fins are used in heat exchangers, which are frequently used for industrial cooling systems. Bacteria and fungi can survive on the surface of aluminum fins and cause contamination of the air to be conditioned. Therefore, hydrophilic, anticorrosive and antibacterial coatings have been developed for aluminum fins [1]. In addition to its anti-corrosive effect, the hydrophilic coating increases the wettability of the applied surface by reducing its hydrophobic property. If the evaporator surface has a hydrophobic structure, the moisture in the environment will condense as drops on the fins. Instead of spreading to the surface, the water molecules on the surface in the form of drops will create resistance against the air passing through the fins of the evaporator, causing an increase in pressure between the evaporator inlet and outlet, while adversely affecting the heat transfer. Min et al. investigated the surface wettability of the hydrophilic coated evaporator and the pressure change in the long-term operating conditions of the evaporator, and it was determined that the hydrophilic coated surface reduced the pressure drop by $34 \%$ [2]. Shen et al. applied different concentrations to improve the hydrophilic coating applied to the copper fin evaporators. They investigated the increase in evaporator capacity for $20 \%, 50 \%$ and $80 \%$ relative humidity conditions, respectively, and observed that the capacity increased by $1.3 \%, 2.5 \%$ and $5 \%$ 
[3]. Moallem et al. examined the freezing behavior of hydrophilic and hydrophobic coated microchannel heat exchangers. They found that hydrophobic and hydrophilic coated heat exchangers freeze after 13 minutes and 20 minutes, respectively, and that the cooling performance of hydrophilic coated microchannel heat exchangers is $4.5 \%$ better [4].

In addition to the geometry of the evaporators, the fins used, the material produced and the applied coatings, one of the parameters that change the cooling capacity is to accelerate the evaporation of the standard liquids and refrigerants passing through the evaporator tubes. Developing technology has led to the enhancement of in-tube evaporation used in many air conditioning and cooling systems. Considering the improvement of the total heat transfer of the evaporator, it is necessary to consider the external heat transfer properties of the evaporator as well as the heat transfer properties of the tube flow [5,6]. Türkan et al. investigated the effect of corrugated and non-corrugated tubes on the thermal capacity theoretically and experimentally and observed that the system capacity increased by $3.24 \%$ when grooved tubes were used [7]. However, researches in the literature using various techniques (both experimental and theoretical) are given in Table 1 [8-11].

Table 1. Studies published in the literature for grooved evaporator designs

\begin{tabular}{|c|c|c|c|c|c|c|}
\hline Authors & Tube type & $\mathrm{d}(\mathrm{mm})$ & Refrigerant & $\Gamma\left(\mathrm{kg} / \mathrm{m}^{2} \mathrm{~s}\right)$ & $\mathrm{q}\left(\mathrm{kW} / \mathrm{m}^{2}\right)$ & $\begin{array}{c}\text { Performance } \\
\text { increase }\end{array}$ \\
\hline Min et al [3] & $\begin{array}{l}\text { Smooth / Smooth } \\
\text { hydrophilically }\end{array}$ & 9.52 & - & - & - & $\% 1.3-5$ \\
\hline Moallem et al [4] & $\begin{array}{l}\text { Smooth/ Smooth } \\
\text { hydrophilically }\end{array}$ & - & - & - & $17-21$ & $\% 4.5$ \\
\hline Türkan et al [7] & $\begin{array}{l}\text { Smooth tube/ } \\
\text { Helical dimpled tube }\end{array}$ & 7.94 & R744 & 300 & 7.5 & $\% 1.03$ \\
\hline Shafaee et al [8] & $\begin{array}{l}\text { Smooth tube/ } \\
\text { Helical dimpled tube }\end{array}$ & 9.52 & R600a & $155-470$ & $6.27-15.8$ & $\% 10.6$ \\
\hline Lillo et al [9] & Smooth tube & 6.00 & R32 & $145-507$ & $2.4-41.2$ & - \\
\hline Chen et al [10] & $\begin{array}{l}\text { Smooth tube/ } \\
\text { two three- } \\
\text { dimensional dimpled } \\
\text { grooved tubes } \\
\text { Smooth tube/ }\end{array}$ & 12.7 & $\mathrm{R} 410 \mathrm{~A}$ & $60-175$ & $17.5-35.2$ & $\% 4.87$ \\
\hline He et al [11] & $\begin{array}{l}\text { Herringbone micro- } \\
\text { fin tube }\end{array}$ & 9.52 & R290 & $90-245$ & $10.55-12.78$ & $\% 8.43$ \\
\hline Guo et al [12] & $\begin{array}{l}\text { Smooth tube/ } \\
\text { Herringbone micro- } \\
\text { fin tube }\end{array}$ & 12.7 & R32 & $50-150$ & $13.9-36$ & $\% 7.9$ \\
\hline $\begin{array}{l}\text { Nascimento et al } \\
{[13]}\end{array}$ & $\begin{array}{l}\text { Smooth tube/ } \\
\text { surface-enhanced } \\
\text { tube }\end{array}$ & 7.94 & $\mathrm{R} 410 \mathrm{~A}$ & $70-200$ & $10-35$ & $\% 1.79$ \\
\hline
\end{tabular}

Karabulut et al. numerically examined the effects of fins arranged in a flat and zigzag pattern on heat transfer and observed that the heat transfer amount of the channel with zigzag blades was $9 \%$ better than the straight duct [14]. Naik et al. designed a new heat exchanger by positioning a cylinder and fins at an angle of $15^{\circ}$ to the duct where the flow occurs. As a result, with the energy and exergy analysis, it was stated that the irreversibility in the system was due to temperature change rather than design [15]. Bahmanabadi et al. studied experimentally the performance of a thermosyphon heat pipe with novel radially rectangular-grooved and radially inclined triangular-grooved evaporator surfaces. It was determined that the radially rectangular grooved and radially inclined triangular grooved surfaces with the same heat transfer area increased by $22.9 \%$ and $36.13 \%$, respectively, compared to the smooth surface [16]. Celik and Nsofor studied the performance of two cooling systems with grooved tube and regular tube evaporators which had the same size using isobutane (R-600a) as the working fluid. It was observed that the grooved tube evaporator system has higher COP and heat exchanger efficiency [17]. 
In this study, the effects of finned tube evaporator and hydrophilic coating, which are among the evaporator types used in cooling and heating applications, on system performance were analyzed. The aim of the study is to investigate theoretically and experimentally the effect of grooved and hydrophilic coated evaporators on vertical type open positive industrial refrigerators. In this context, a cooling test mechanism was installed and the changing temperature, pressure and power values were recorded instantly and presented in graphs, and recommendations were made to improve the cooling system economically and technically by determining their effects on the system performance.

\section{MATERIAL METHOD}

In this study, it is aimed to compare and analyze different types of evaporators in an industrial refrigeration system. M1 type vertical, open, vapor compression industrial refrigeration system operating with R290 (Propane) refrigerant was designed, manufactured and tested by calculating the cooling load. Tests were carried out in the test room under Class $-325{ }^{\circ} \mathrm{C}$ temperature and $60 \%$ relative humidity conditions. In addition, the tests were conducted equally and in accordance with the ISO 23953-2 standard, using equipments with the same properties in both types of evaporators. At this point, from the evaporators whose properties are given in Table 2, 1/2 "diameter straight tube evaporator and 3/8" diameter corrugated tube, hydrophilic coated evaporator were connected to the test setup and the experimental data were recorded.

Table 2. Technical and geometrical characteristics of evaporators tested in experimental setup

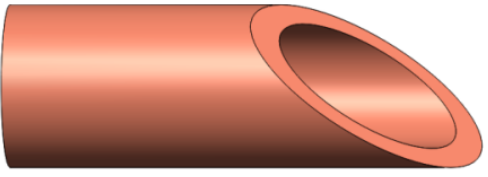

$1 / 2$ " smooth tube

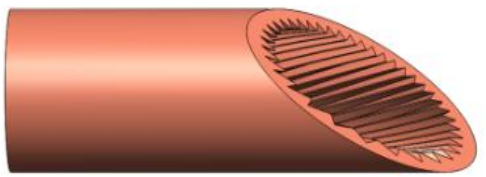

$3 / 8$ " grooved tube

\begin{tabular}{lccc}
\hline Type of Tube & Smooth tube & Grooved Tube & Unit \\
\hline Geometry-Diameter & $40 \times 35-1 / 2 "$ & $35 \times 35-3 / 8^{\prime \prime}$ & inc \\
Number of Tube & 32 & 40 & - \\
Heat Exchanger Surface & 22.1 & 26.1 & $\mathrm{~m}^{2}$ \\
Tube outer diameter $(d o)$ & 12.700 & 9.52 & $\mathrm{~mm}$ \\
Tube inner diameter $(d i)$ & 11.360 & 8.82 & $\mathrm{~mm}$ \\
Tube grooved diameter $(d t)$ & - & 8.46 & $\mathrm{~mm}$ \\
Grooved helght $(f)$ & - & 0.2 & $\mathrm{~mm}$ \\
Grooved apex angle $(\theta)$ & - & $53^{\circ}$ & degree \\
Grooved angle $(\beta)$ & - & $20^{\circ}$ & degree \\
Number of grooved $(n)$ & - & 65 & - \\
Coated Aluminium & - & hydrophilically $(0.02 \mathrm{~mm})$ & $\mathrm{mm}$ \\
Refrigerant liquid & $\mathrm{R} 290$ (propane) & $\mathrm{R} 290($ propane $)$ & - \\
Refrigerant quantities & 700 & 430 & $(\mathrm{~g})$ \\
Environmental temperature & 24.77 & 24.51 & ${ }^{\circ} \mathrm{C}$ \\
\hline
\end{tabular}

In the produced experimental setup, two condensers and compressors are operated together with an evaporator with two inlets and outlets. Two pressure zones were created in the system using capillary tubes. Experimental set up and its measurement points are given in Figure 1. 


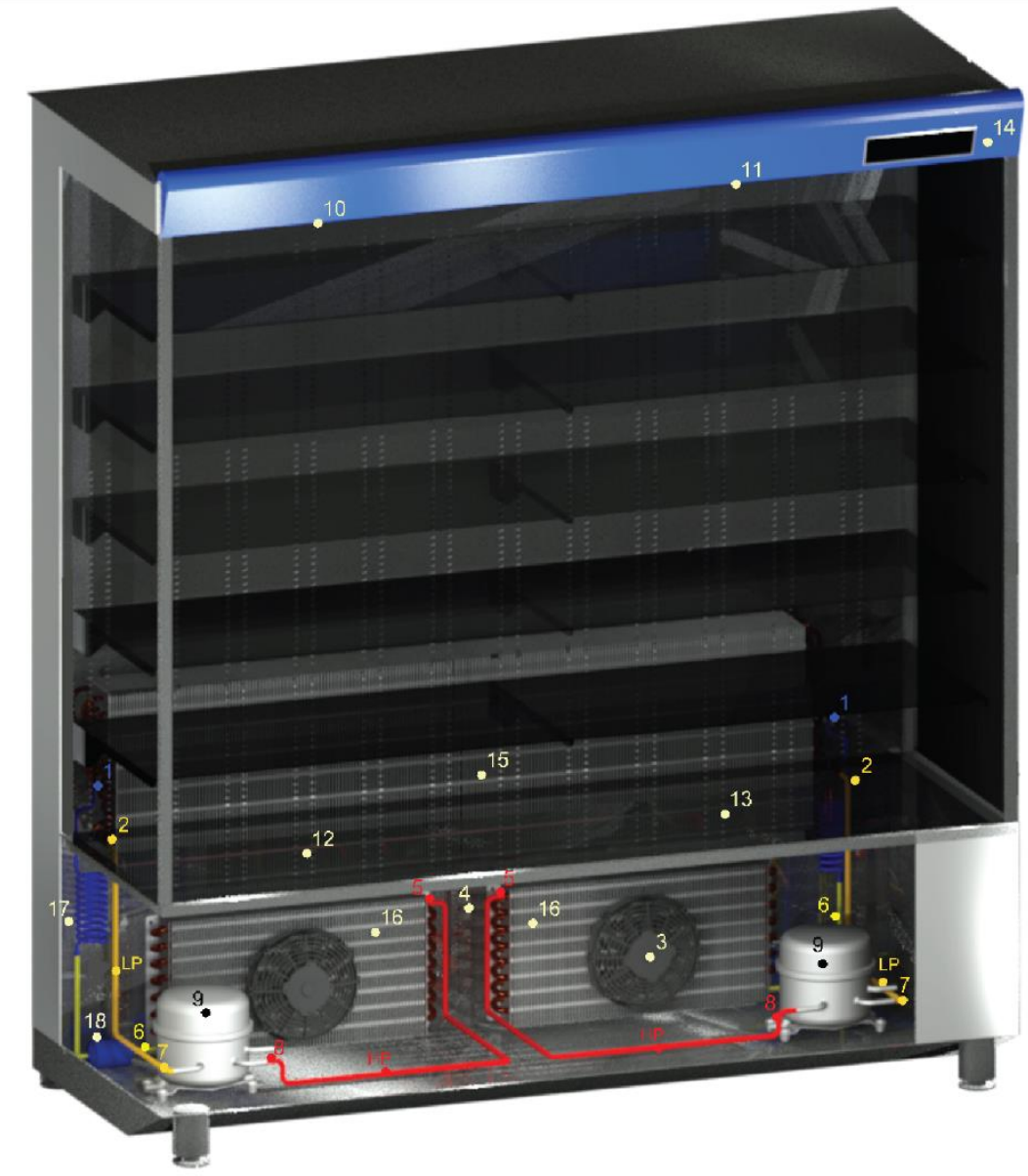

Evaporator inlet temperature value Evaporator output temperature value Condenser air inlet temperature value Condenser air outlet temperature value Condenser gas inlet temperature value Condenser liquid output temperature value Compressor suction temperature value Compressor discharge line temperature value Compressor body temperature value Left side blowing air temperature value
11

12

13

14

15

16

17

18

HP

LP
Right side blowing air temperature value Left side intake air temperature value Right side intake air temperature value Temperature and relative humidity sensor Evaporator Condenser Capillary tube Dryer High pressure value Low pressure value

Figure 1. Cooling system and measuring points

The experiments were carried out in the test room with calibrated test devices within the scope of TS EN ISO 23953-2 standard. Cooling performance of the system, energy consumption, temperature measurements, pressure measurements and energy efficiency tests were performed. While performing these tests, temperature measurements were taken every minute by means of thermocouples from certain points of cooling systems equipment (compressor, condenser and evaporator inlet-outlet temperature values). Information for measurement equipments used in prototype production and tests is given in Table 3. 
Table 3. Measurement devices and their technical features used in prototype production and tests

\begin{tabular}{lcccc}
\multicolumn{1}{c}{ Device } & Model & Measuring Range & Unit & Accuracy \\
& & & & \\
\hline Thermocouples & Omega, CL-23A & $-40 /+150$ & ${ }^{\circ} \mathrm{C}$ & $\pm \% 0.02$ \\
Pressure transmitter & Eliwell, HP & $0-30$ & bar & \pm 0.1 \\
Pressure transmitter & Eliwell, LP & $0.5-8$ & bar & \pm 0.01 \\
Thermohygrometer & Rotronic, M23W2HT-1X & $0 /+50$ & ${ }^{\circ} \mathrm{C} / \% R H$ & \pm 0.03 \\
& E+E Electronic, EE66-VA3 & $0-100$ & & $\pm \% 1.5$ \\
Anemometer & EE660-V7 & $0-2$ & $\mathrm{~m} / \mathrm{s}$ & \pm 0.01 \\
Vacuum pump & Value, VP2200 & $0.04-0.8$ & Pa & \pm 0.02 \\
Digital scales & Value, VES-100B & $0-100$ & $g$ & $\pm \% 0.05$ \\
Digital manifold & Testo, 550 & $-50 /+150$ & ${ }^{\circ} \mathrm{C} /$ bar & $\pm 0.1{ }^{\circ} \mathrm{C}$ \\
& & $-1 /+60$ & & \pm 0.01 \\
Energy analyzer & Janitza, UMG508 & & Ampere & Current \\
& & & Volt & Voltage 0.2 \\
Flowmeter & Siemens, SITRANS FC MASS & $0-1000$ & $\mathrm{~kg} / \mathrm{h}$ & $\pm \% 0.1$ \\
\hline
\end{tabular}

\subsection{Theoretical Analysis}

It is important to apply the first and second law analyses of thermodynamics in order to determine the performance criteria of an industrial cooling system. Evaporator capacity of the industrial cooler can be calculated with the following equation:

$$
\dot{Q}_{e}=\dot{m}_{r} \cdot\left(h_{1}-h_{4}\right)
$$

The compressor power that will meet the cooling load in the industrial cooler and create the desired pressure difference in the cooling system can be determined with the following equation $[18,19]$ :

$$
\dot{W}_{c}=\dot{m}_{r} \cdot\left(h_{2}-h_{1}\right)
$$

Cooling coefficent of performance of the industrial refrigeration cycle [20]:

$$
C O P=\frac{\dot{Q}_{e}}{\dot{W}_{c}}
$$

Carnot coefficent of performance of the industrial refrigeration cycle can be calculated as below:

$$
C O P_{t r}=\frac{T_{L}}{T_{H}-T_{L}}
$$

The second law efficiency of the industrial cooling system can be found by the ratio of the coefficent of performance of cooling the system to the Carnot coefficent of performance at the same conditions:

$$
\eta=\frac{C O P}{C O P_{t r}}
$$

Mass flux is calculated with the following equation: 


$$
\Gamma=\frac{\dot{m}_{r}}{A_{c}} .
$$

Using the experimental data, the heat transfer coefficient resulting from the difference between the temperature of the refrigerant inside the evaporator $\left(T_{e, r}\right)$ and the air temperature outside the evaporator $\left(T_{a}\right)$ can be determined using the following equation [21]:

$$
h_{e x p}=\frac{\dot{Q}_{e}}{A_{\mathrm{s}} \cdot\left(T_{a}-T_{e, r}\right)} .
$$

Bond number, which is used to describe the contribution of the liquid-gas interface to heat transfer, which will be formed by the evaporation of the R290 refrigerant in the evaporator, is known as the ratio of gravitational forces to surface tension forces and can be calculated with the following equation [22]:

$$
B o=\frac{g \cdot \pi \cdot \rho_{l} \cdot f \cdot d_{t}}{8 \cdot n \cdot \sigma} .
$$

The Froude number is used to define the flow characteristic due to the dual phase flow formed in the evaporator and can be calculated with the following equation:

$$
F r=\frac{\Gamma^{2}}{g \cdot \rho_{v}^{2} \cdot d_{t}} .
$$

In order to determine the flow type in the case of two-phase flow in pipes containing grooved, the proposed Reynolds number is given with the following equation [23]:

$$
R e_{x}=\frac{\frac{\text { z.f.n. }(1-\sin (\theta / 2)}{\pi \cdot d_{t} \cdot \cos (\theta / 2)}+1}{\cos (\beta)} .
$$

The two-phase flow that occurs in the evaporator makes it difficult to resolve heat transfer. One of these difficulties is determining the evaporation heat transfer coefficient. Zhang et al. Presented the following equation to find the heat transfer coefficient in two-phase flow developed for azeotropic refrigerants [24, 25]:

$$
\begin{aligned}
& N u_{c v}=\left(0.023 \cdot\left(\frac{\Gamma \cdot d_{t}}{\mu_{l}}\right)^{0.8} \cdot P r_{l}^{1 / 3}\right) \cdot\left((1-\mathrm{x})+2.63 \cdot \mathrm{x} \cdot\left(\frac{\rho_{l}}{\rho_{v}}\right)^{1 / 2}\right)^{0.8}, \\
& h_{c v}=\left(\frac{k_{l}}{d_{t}}\right) \cdot N u_{c v} \cdot R e_{x}^{2.14} \cdot(B o \cdot F r)^{-0.15} \cdot\left(\frac{d_{o}}{d_{t}}\right)^{0.59} \cdot\left(\frac{100}{\Gamma}\right)^{0.36}, \\
& h_{n b}=55 \cdot \operatorname{Pr}^{0.12} \cdot(-\log \operatorname{Pr})^{-0.55} \cdot \mathrm{M}^{-0.5} \cdot \mathrm{q}^{2 / 3} \cdot A_{c} \cdot X_{t t}^{0.36} \cdot\left(\frac{d_{o}}{d_{t}}\right)^{0.38}, \\
& X_{t t}=\left(\frac{1-\mathrm{x}}{\mathrm{x}}\right)^{0.9} \cdot\left(\frac{\rho_{v}}{\rho_{l}}\right)^{0.5} \cdot\left(\frac{\mu_{l}}{\mu_{v}}\right)^{0.1}, \\
& h_{t p}=h_{n b}+h_{c v} .
\end{aligned}
$$

With the developing technology and industry day by day, $\mathrm{CO}_{2}$ emissions are increasing. Heat pumps used in cooling and heating applications are known to produce much lower $\mathrm{CO}_{2}$ emissions than other fossil fuels. With the improvement refrigerant technology, the use of natural refrigerants in cooling systems 
enables heat pumps to be much more environmentally friendly. Using the equation below, it can be calculated how many kilograms of $\mathrm{CO}_{2}$ emitted annually for the preferred refrigerant [26]:

$$
C O_{2 e}=\left(T_{R 410} * 10^{-3}\right) * t_{\text {year }} *\left(G W P_{C O_{2} / 410 a} *\left(0.5 *\left(R_{32}+R_{125}\right)\right)\right)
$$

\section{RESULTS AND DISCUSSIONS}

The experimental set-up designed, produced and analyzed within the scope of ISO 23953-2 standard is shown in Figure 1. In this study, two alternatives for evaporators used in refrigeration cycles were examined theoretically and experimentally. First system a 1/2 "pipe diameter smooth tube and hydrophilic uncoated evaporator was used, in the second system a 3/8" diameter grooved tube and hydrophilic coated lamellar evaporator was used. Thermodynamic properties of the refrigerant used in evaporator theoretical and experimental values are given in Table 4.

Table 4. Thermodynamic properties of refrigerant used in theoretical and experimental values

\begin{tabular}{cll}
\hline & Smooth tube evaporator & Grooved tube evaporator \\
\hline$\Gamma\left(\mathrm{kg} / \mathrm{m}^{2} \mathrm{~s}\right)$ & 294.375 & 177.452 \\
$\mathrm{X} \mathrm{tt}$ & $\mathrm{N} / \mathrm{A}$ & 0.299 \\
$\mathrm{P}_{\mathrm{rl}}$ & 23.085 & 23.085 \\
$\mathrm{Bo}$ & $2.94 \mathrm{E}-03$ & $2.94 \mathrm{E}-03$ \\
$\mathrm{Fr}$ & 7345.670 & 7345.670 \\
$\mathrm{Nu}$ & 585.633 & 585.633 \\
$\mathrm{X}$ & 0.35 & 0.334 \\
$\mathrm{M}(\mathrm{kg} / \mathrm{kmol})$ & 0.0441 & 0.0441 \\
$\mu \mathrm{v}$ & $5.61 \mathrm{E}-06$ & $5.61 \mathrm{E}-06$ \\
$\mu 1$ & 0.000148431 & 0.000148431 \\
$\mathrm{kl}(\mathrm{W} / \mathrm{mK})$ & 0.0153 & 0.0153 \\
$\rho_{\mathrm{v}}\left(\mathrm{kg} / \mathrm{m}^{3}\right)$ & 7.187 & 7.187 \\
$\rho_{\mathrm{L}}\left(\mathrm{kg} / \mathrm{m}^{3}\right)$ & 535.026 & 535.026 \\
$\sigma(\mathrm{N} / \mathrm{m})$ & $2.14 \mathrm{E}-02$ & $2.14 \mathrm{E}-02$ \\
$\operatorname{Pr}(\mathrm{pressure} / \mathrm{critical}$ pressure $)$ & $\mathrm{N} / \mathrm{A}$ & 0.081 \\
\hline
\end{tabular}

It is known that by increasing the effect of frictional forces on hydrophilic coated lamellae, water droplets do not remain in a spherical form on the surface, but tend to spread on the surface. Due to this effect of water drops, the surface areas in contact with the blades will increase and faster evaporation and slow ice formation will be observed. Thus, the water resistance on the coverslips is weakened and the thermal resistance caused by the water decreases and accordingly an increase in heat transfer is expected. Gibbons et al. (2020) examined the water droplet on the hydrophilic coated surface and the heat and mass transfer of the water droplet showing superhydrophobic properties and found that the evaporation rate of the water droplet on the hydrophilic coated surface was $34 \%$ faster [27].

The total energy consumption and charged R-290 refrigerant mass in the first and second systems in the experimental setup were measured as $24.64 \mathrm{kWh}, 23.39 \mathrm{kWh}$ and 700 grams, 430 grams, respectively. As a result of these data, it is calculated that the second system is $5.073 \%$ and $38.57 \%$ more efficient in terms of energy efficiency and refrigerant mass.

In the first experiment, the changing of the inlet and outlet air temperature during the experiment for the evaporator with 1/2" tube diameter without groove and lamellar coating is given in Figure 2. Looking at the air temperatures in Figure 2, the system performs defrosting every 3 hours. At the same time, the average temperatures of the air entering and leaving the evaporator are seen as $6.327^{\circ} \mathrm{C}$, and $-0.407^{\circ} \mathrm{C}$, respectively. In this case, the temperature difference of the cooled air is calculated as $\Delta \mathrm{T}=6.797^{\circ} \mathrm{C}$. 


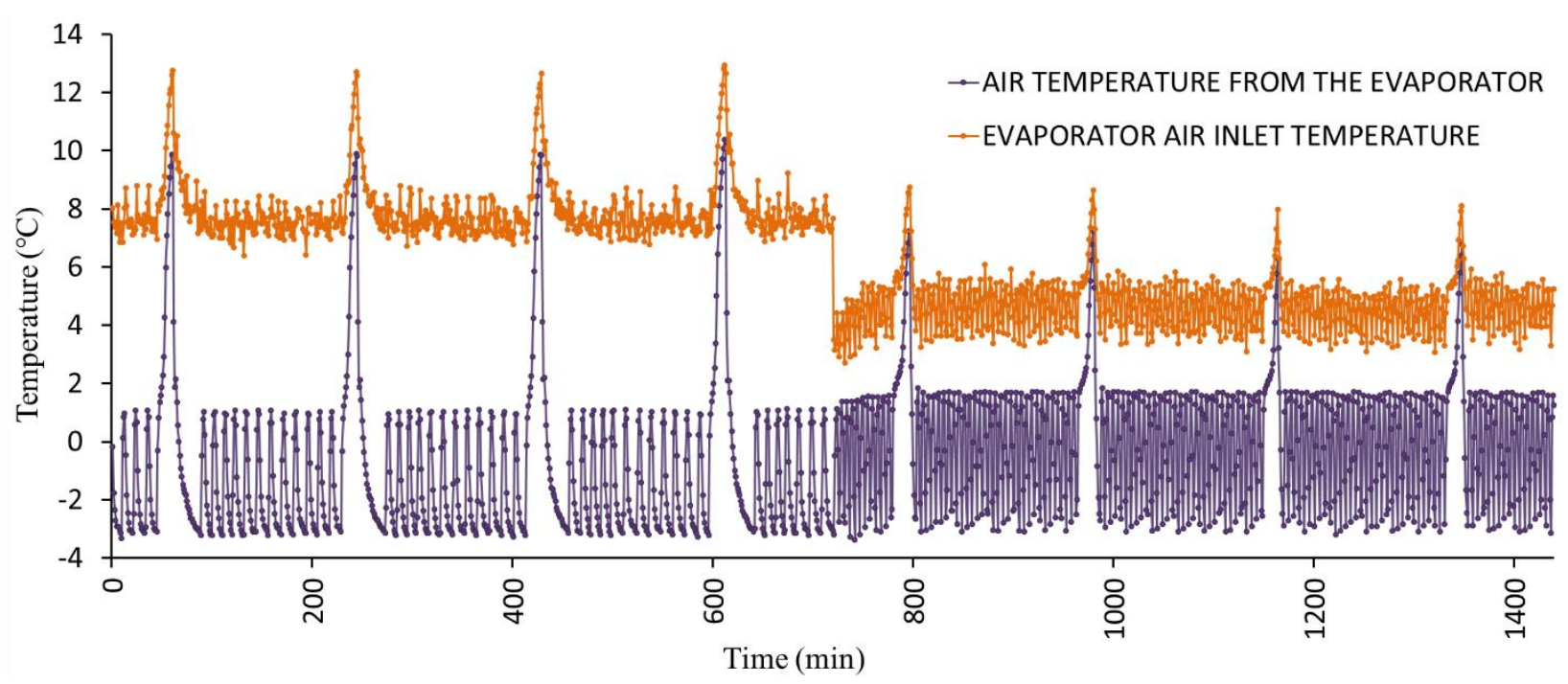

Figure 2. 1/2" evaporator air inlet-outlet temperature change over time

In the second experiment, the change of inlet and outlet air temperature over time for hydrophilic coated evaporator with 3/8" diameter grooved tubes is given in Figure 3. The average temperatures of the air entering and leaving the evaporator for the second experiment are $5.877^{\circ} \mathrm{C}$ and $-1.175^{\circ} \mathrm{C}$, respectively. In this case, the temperature difference of the cooled air is calculated as $\Delta \mathrm{T}=7.052{ }^{\circ} \mathrm{C}$. Considering the temperature difference between the first and second systems, it is seen that the evaporator in the second system is more effective in terms of heat transfer.

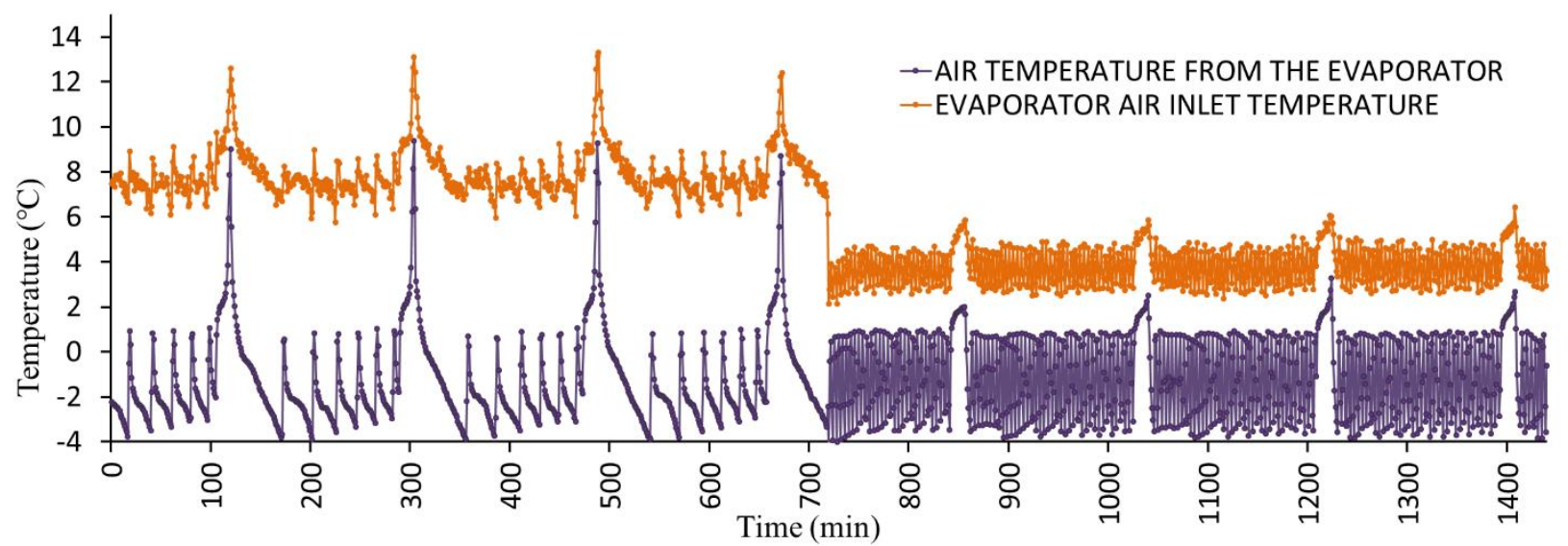

Figure 3. 3/8" evaporator air inlet-outlet temperature change over time

As can be seen in Figure 4, the cooling fluid inlet temperatures of the evaporators with 1/2 "diameter grooved tube and 3/8" diameter grooved tube and hydrophilic coated lamellae are shown over time. In accordance with the standard, the experimental setup is operated for a total of 24 hours, with 12 hours of lighting and cabin doors open and the next 12 hours with lighting and covers closed. Figure 4 shows that the refrigerant temperature entering the grooved tube evaporator with a diameter of $3 / 8$ " is slightly lower. At the same time, the defrost temperature appears to be lower in the hydrophilic coated evaporator. 


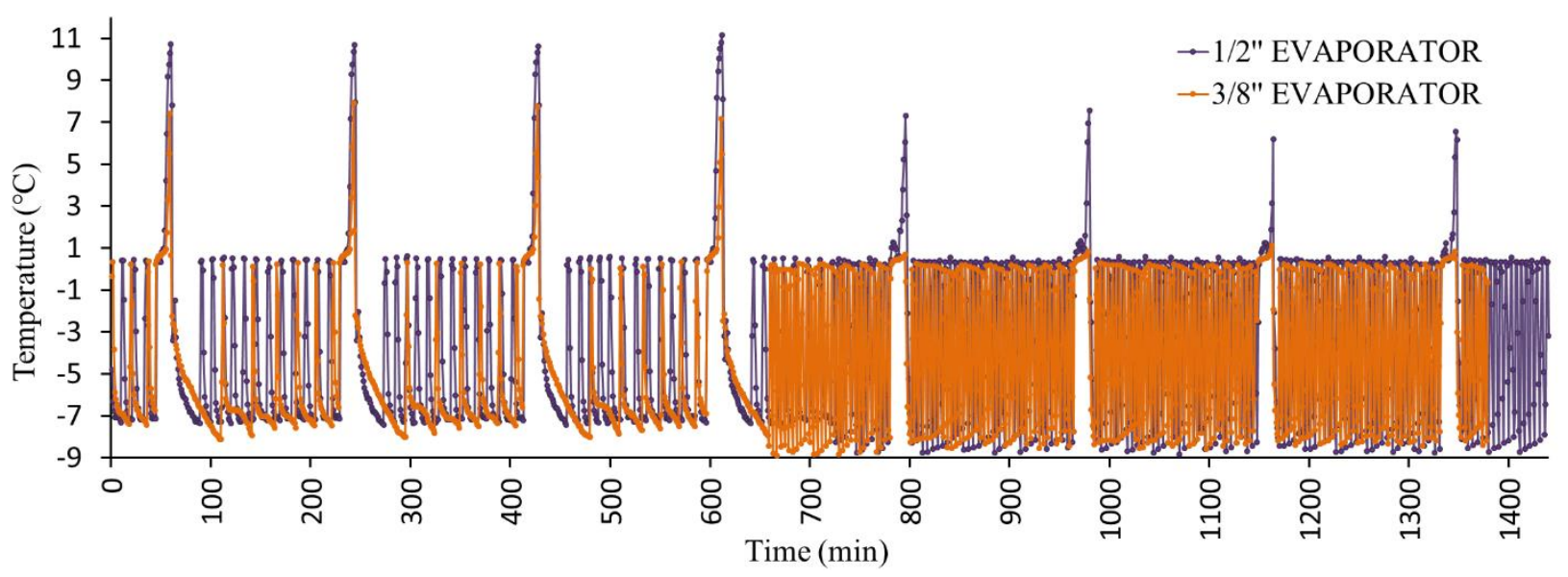

Figure 4. Investigation of the change of refrigerant temperature over time at the inlets of the two evaporators

On the other hand, Figure 5 was created by measuring the refrigerant temperatures at the outlet of the evaporators every minute during the 24-hour experiment period for two evaporators. As seen in Figure 5 , the outlet temperature of $3 / 8$ " diameter grooved tube evaporator is higher than the other. This indicates that the 3/8" diameter grooved tube evaporator draws more heat from the air. However, a small temperature difference is observed between the two evaporators, which is due to the grooved evaporator tube with a diameter of $3 / 8$ ". At the same time, when we look at the maximum temperature values during defrost, it is observed that the $1 / 2$ " evaporator catches the highest temperature during each defrost. The reason for this is thought to be that, thanks to the hydrophilic coating in the 3/8" tube, the ice spreading on the tube wall gets rid of the tube more quickly. Kim et al. conducted the performance analysis by applying different types of coatings to heat pipe heat exchangers, and found an increase of $61 \%$ in heat flux for hydrophilic coated heat pipes [28].

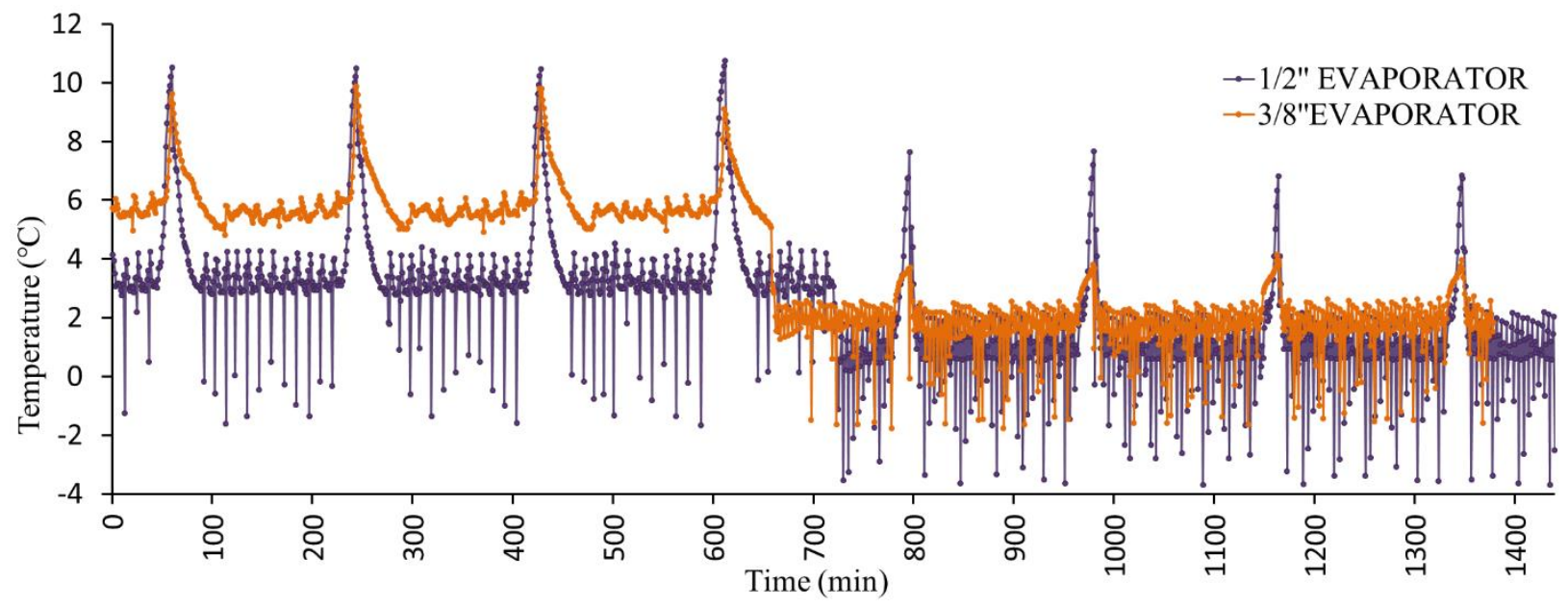

Figure 5. Investigation of the change of refrigerant temperature over time at the outlet of two evaporators

Figure 6 shows the average power consumption values calculated every 2 hours. Looking at the graph, it is seen that the power consumption of $3 / 8$ " evaporator is lower than the other evaporators. It was observed that $3 / 8$ " evaporator decreased power consumption compared to other evaporators especially in the last 12 hours section where lights and covers were closed. Figure 7 shows the coefficient of performance (COP) values calculated against the determined power values. In coefficient of 
performance values, the average coefficient of performance value for $1 / 2$ " evaporator was 2.807 , while it was calculated as 3.013 for $3 / 8$ " evaporator.

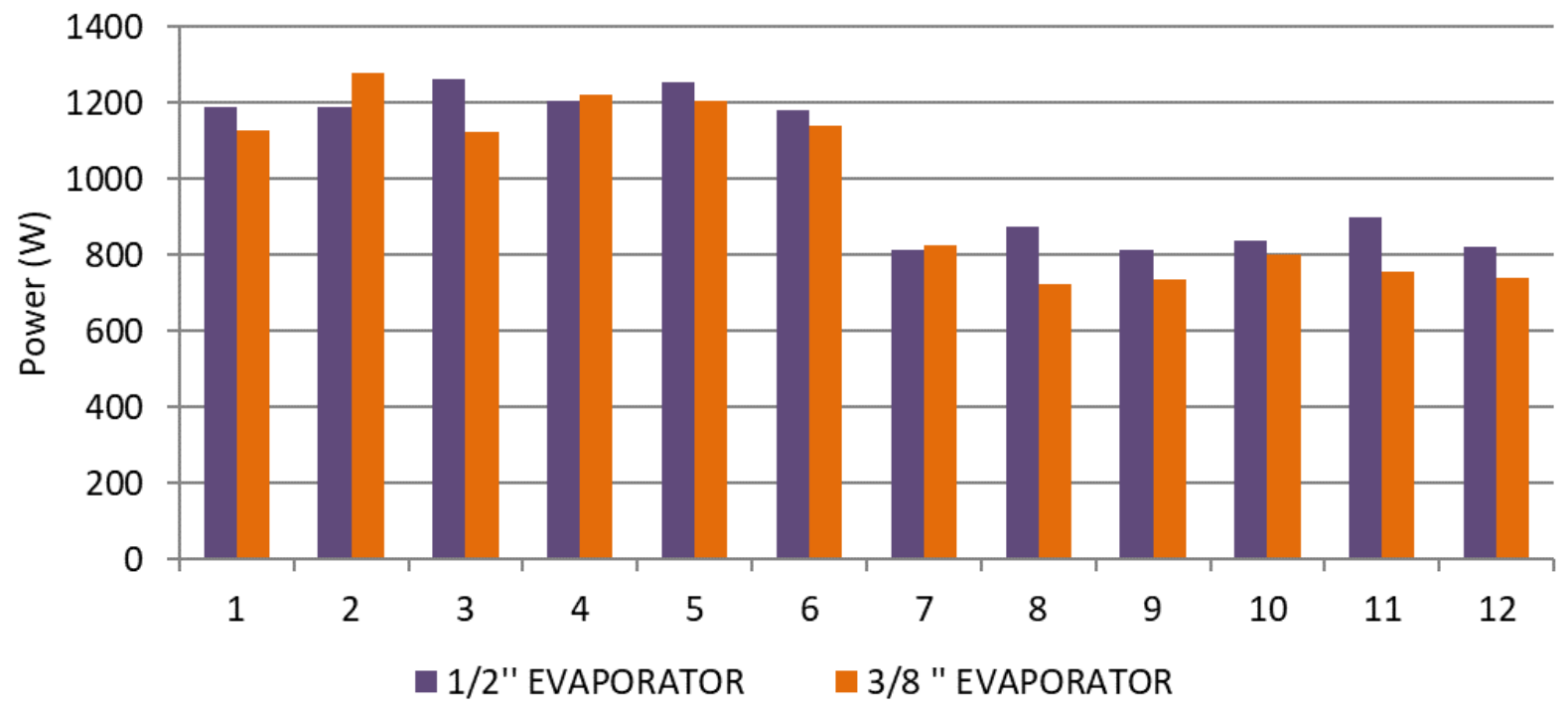

Figure 6. Comparison of average power values calculated every 2 hours

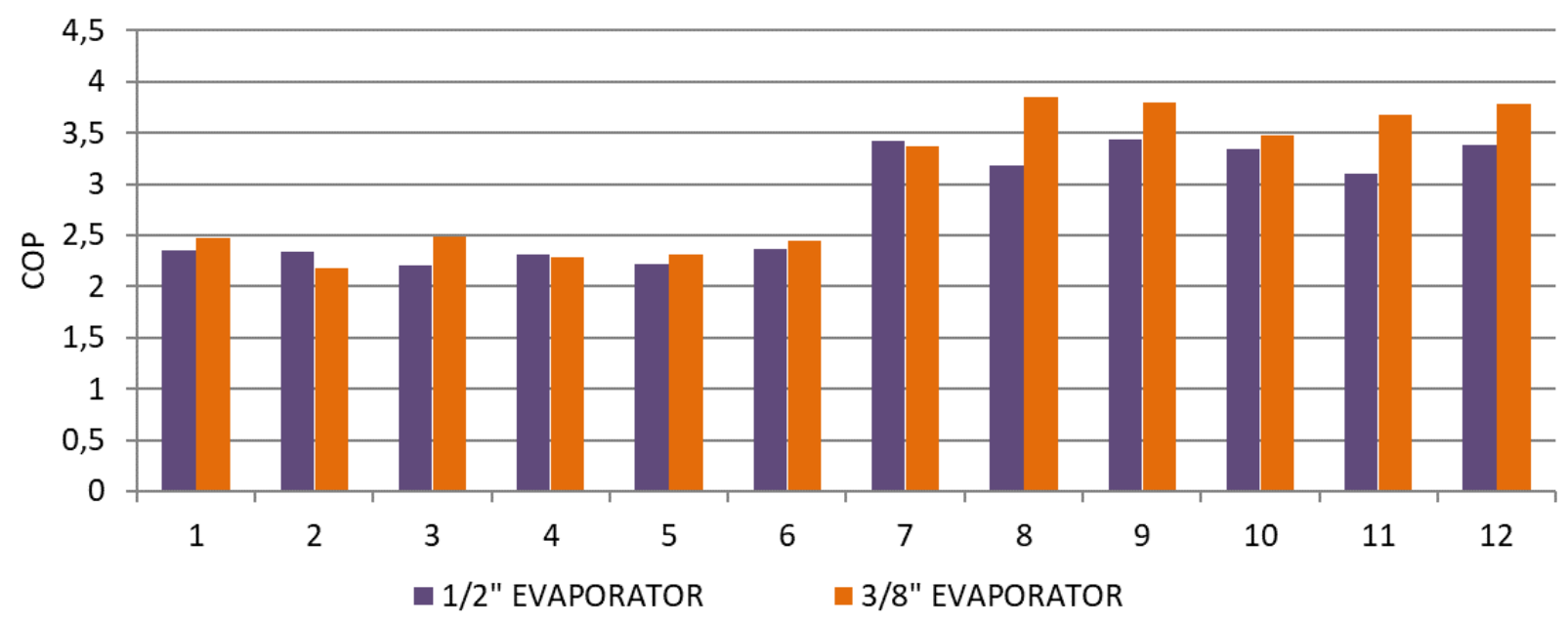

Figure 7. Comparision of COP values calculated every 2 hours

The second law efficiency of both evaporators is given in Figure 8. The second law efficiency values are ranging from $20.551-32.012 \%$ and $20.925-36.921 \%$ for $1 / 2 "$ and $3 / 8 "$ evaporators, respectively. The average second law efficiency values of $1 / 2$ " and 3/8" evaporators were determined as $26.126 \%$ and $28.898 \%$, too. The highest exergy efficiencies were $32.012 \%$ for $1 / 2$ " evaporator and $36.921 \%$ for $3 / 8$ " evaporator. Evaluating Figure 8, the second-law efficiency of 3/8" diameter grooved tube evaporator is $9.593 \%$ higher than the other, meaning that it has a better thermodynamic perfection. 


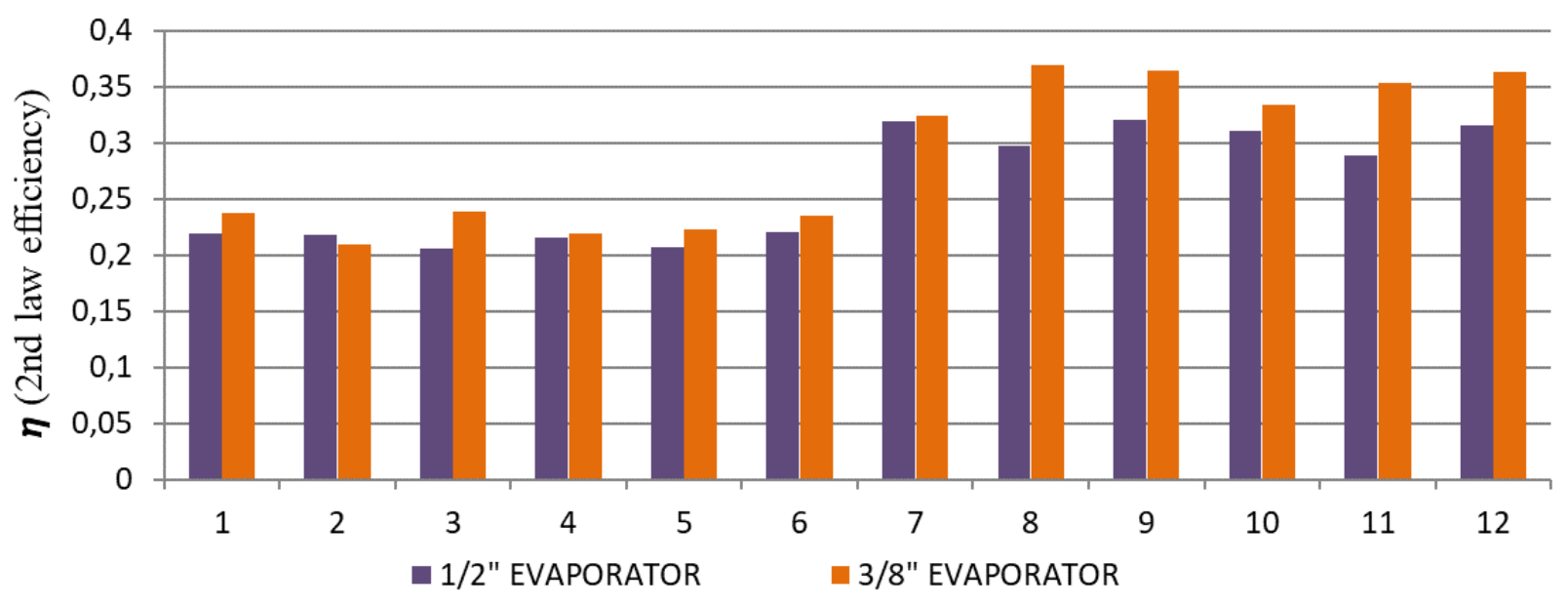

Figure 8. Comparison of the second law efficiency values calculated every 2 hours

As can be seen in Figure 9, the variation of the experimentally calculated heat transfer coefficients for smooth tube evaporator and grooved tube evaporator is given. As can be seen from the graph, it is seen that the heat transfer coefficient of the evaporator with grooved tubes increased by $52.95 \%$ compared to the smooth tube. The heat transfer coefficients of the evaporator containing grooved tubes constantly change over time. However, it seems that its performance is better for all time intervals compared to the smooth tube. This change is thought to be caused by the grooved in the tube continuously increasing the Reynolds number and evaporation potential during two-phase flow, and therefore a constant heat transfer coefficient cannot be calculated. As can be seen from Figure 9, heat transfer coefficients with less variation are calculated for the smooth tube evaporator.

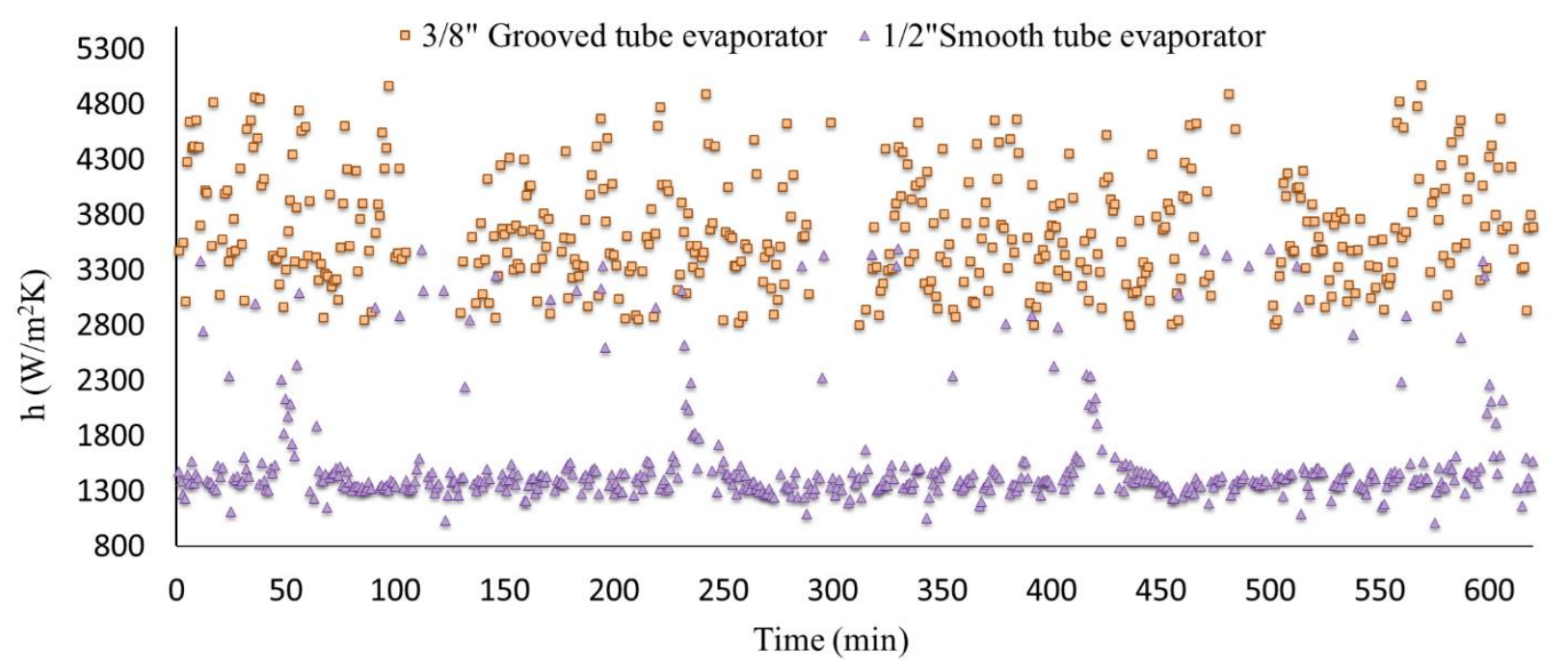

Figure 9. Time dependent changes of the heat transfer coefficients of grooved and smooth tube evaporator calculated by experimental data

In addition to the heat transfer coefficients calculated with experimental data, it is very difficult to mathematically define this two-phase flow occurring in the evaporator. The model developed by Zhang et al. [25] for azeotropic refrigerants were used in this study for R290 (propane), which is one of the natural refrigerants, and the heat transfer coefficients in two-phase flow were calculated and compared with the experimental results. As can be seen from Figure 10, it is observed that the calculated values for R290 (propane) give correct results at the rate of $95.04 \%$. 


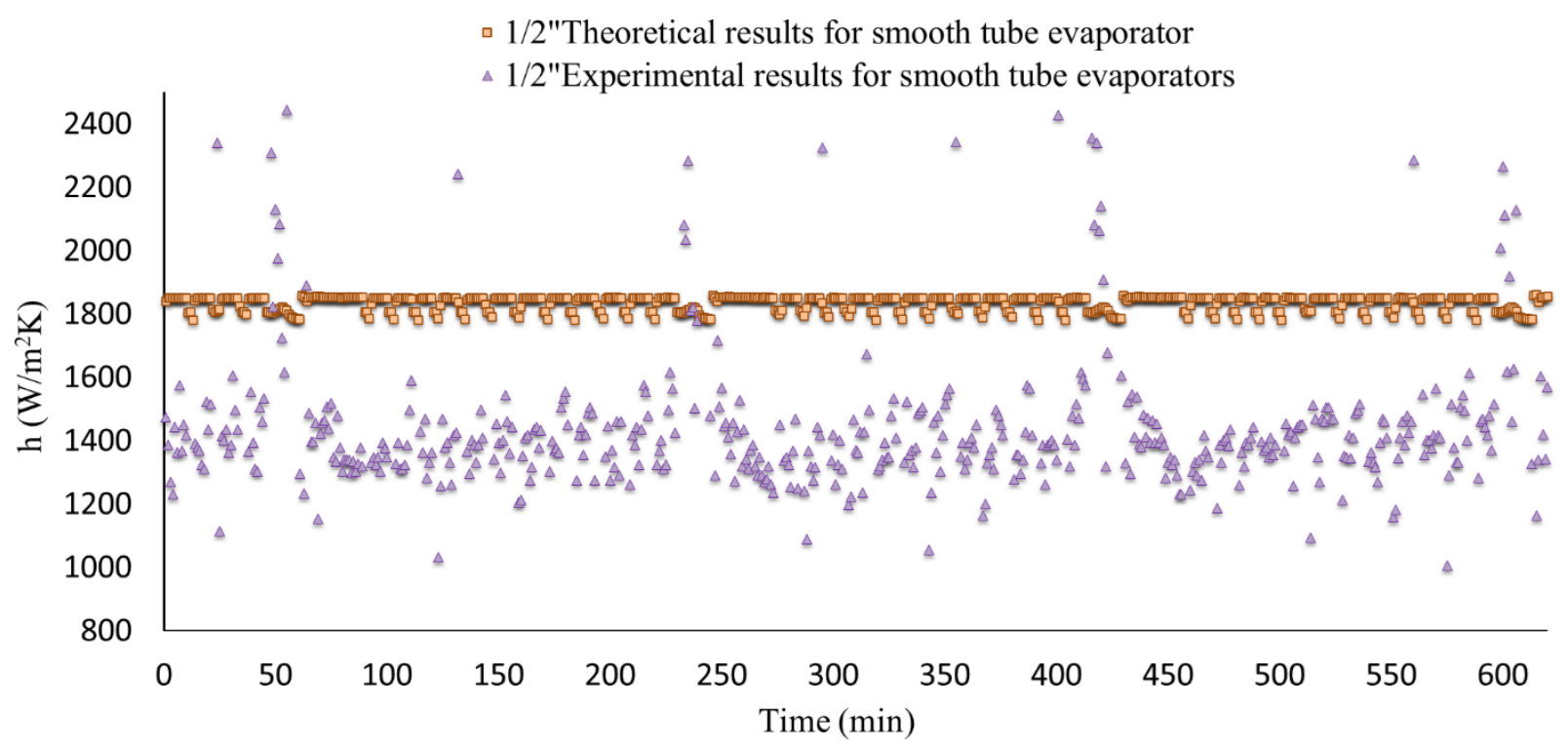

Figure 10. Comparison of the time-dependent changes in the heat transfer coefficients calculated using the model proposed by Cavallini and experimental data for the smooth tube evaporator

As can be seen from Figure 11, when Zhang et al.'s model [25] developed for azeotropic refrigerants is applied to R290 (propane), which is a grooved tube hydropylic-coated natural refrigerant, it was observed that the calculated values correctly estimate $92.10 \%$. Although $92.10 \%$ is an acceptable value, it should be taken into account that if large-power systems are designed with the proposed model, it will cause errors of $7.9 \%$.

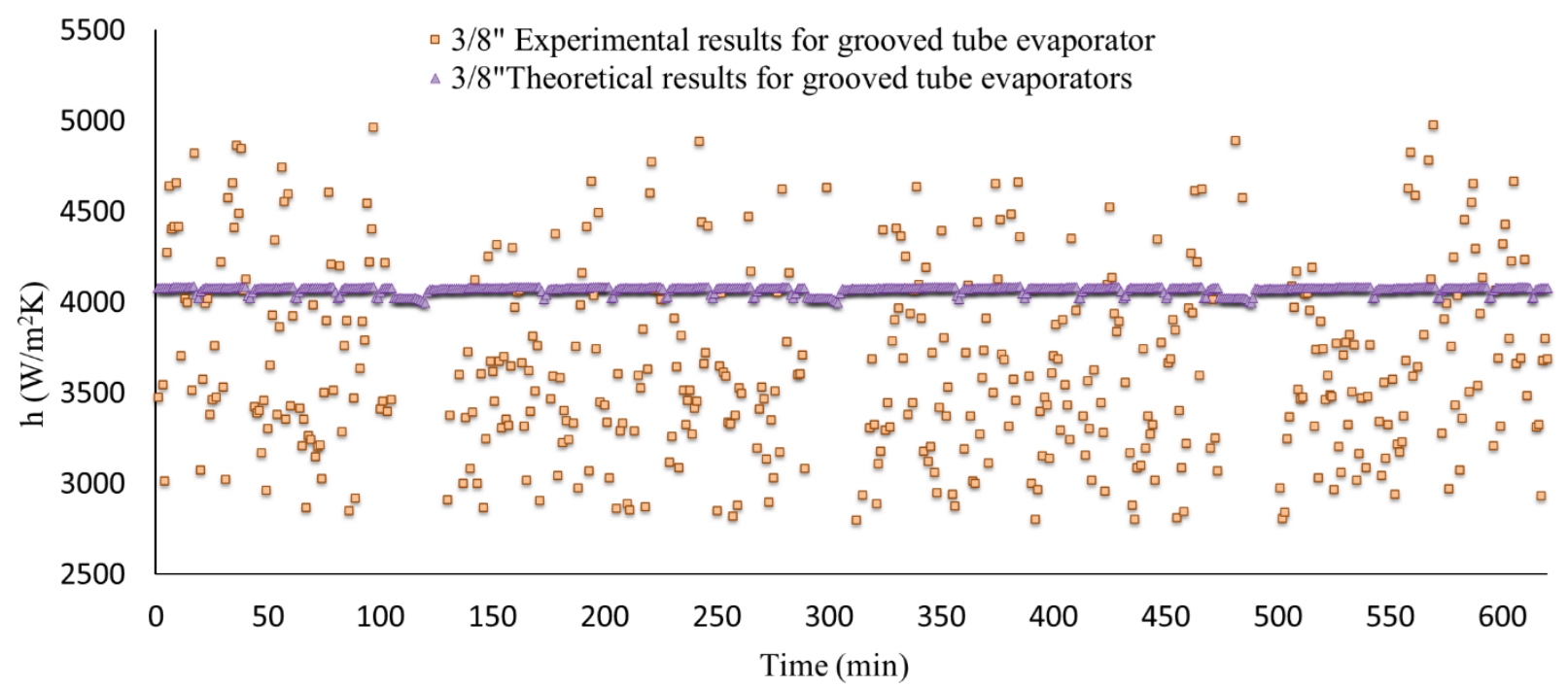

Figure 11. Comparison of the time-dependent changes of the heat transfer coefficients calculated using the model proposed by Cavallini and experimental data for the grooved tube evaporator

Rossetto et al. [29] using R513A refrigerant, found that $3.4 \mathrm{~mm}$ diameter and $300 \mathrm{~mm}$ length, 150 to 800 $\mathrm{kg} / \mathrm{m}^{2} \mathrm{~s}$ mass velocity and 12 to $60 \mathrm{~kW} / \mathrm{m}^{2}$ heat flux ranging. In the study, they determined the average heat transfer coefficient as $150 \mathrm{~kg} / \mathrm{m}^{2} \mathrm{~s}$ flow rate and $12 \mathrm{~kW} / \mathrm{m}^{2}$ heat flux as $5500 \mathrm{~W} / \mathrm{m}^{2} \mathrm{~K}$. In addition, Diani et al. [30] examined the heat transfer coefficients for R1234ze(e) and R134a refrigerants in their experimental study and stated that the heat transfer coefficient was approximately $4000 \mathrm{~W} / \mathrm{m}^{2} \mathrm{~K}$ when the mass velocity was $100 \mathrm{~kg} / \mathrm{m}^{2} \mathrm{~s}$. In this study, the average heat transfer coefficient was determined as $3727.38 \mathrm{~W} / \mathrm{m}^{2} \mathrm{~K}$ in the evaporator, which consists of grooved tubes with an inner diameter of $8.820 \mathrm{~mm}$ and a length of 1525 $\mathrm{mm}$, according to the results obtained with $177.45 \mathrm{~kg} / \mathrm{m}^{2} \mathrm{~s}$ flow rate and 0.33 steam quality. Considering other studies conducted together with this study, it is seen that the effect of flow rate and steam quality on the heat transfer coefficient is quite large. In the study of Çoban et al. [31] where R290 refrigerant was 
used, it was determined that the heat transfer coefficient determined for $424 \mathrm{~kg} / \mathrm{m}^{2} \mathrm{~s}$ flow rate and 0.35 dryness degree was $5000 \mathrm{~W} / \mathrm{m}^{2} \mathrm{~K}$. Apart from this, although it is seen that the models developed for twophase flow in the literature do not fully support the experimental results, it was seen that the mathematical model developed by Zhang et al. used in this study correctly predicted the experimental results between $90 \%$ and $95 \%$.

\section{CONCLUSIONS}

In this study, industrial coolers with different types of evaporators were designed, manufactured and tested. Throughout the experiment, the following successful results were attained:

- In the experimental setups, the energy consumed in the first and second systems and the masses of R-290 refrigerant were measured as $24.64 \mathrm{kWh}, 23.39 \mathrm{kWh}$ and 700 grams, 430 grams, respectively. This shows that the second system is $5.073 \%$ and $38.57 \%$ more efficient in terms of energy efficiency and the refrigerant used, respectively.

- During the experiments, the average temperature difference of the air entering and leaving the evaporator was calculated as $\Delta \mathrm{T}=6.797^{\circ} \mathrm{C}$ and $\Delta \mathrm{T}=7.052{ }^{\circ} \mathrm{C}$ for the first and second systems, respectively. The hydrophilic coating used in the evaporator prevents the formation of resistance to airflow between the evaporator fins by spreading water molecules on the evaporator surface. When two systems are compared in terms of performance, the first system COP value is 2.807, while it is calculated as 3.013 for the second system.

- The average second law efficiency and $\mathrm{CO}_{2}$ emission values of $1 / 2$ " and 3/8" evaporators were found as $26.126 \%, 28.898 \%$ and $4.383 \mathrm{~kg} / \mathrm{year}, 2.692 \mathrm{~kg} /$ year.

- The heat transfer coefficients of the straight tube evaporator and the micro finned tube evaporator were experimentally calculated and it was determined that the heat transfer coefficient of the micro finned tube evaporator increased by $52.95 \%$ compared to the straight tube. In addition, the model developed by Zhang et al [25] to determine the heat transfer coefficients in two-phase flow was applied for the R290 (propane) refrigerant in this study. It was calculated that the applied model predicted $95.04 \%$ correct for smooth tube and $92.10 \%$ for grooved tube.

- It is seen that the internal design of the evaporators used in cooling systems, as well as the external design, significantly affects the heat transfer and cooling capacity. For this study, it has been observed that the grooved tube evaporator has a better cooling performance compared to the straight tube evaporator.

- The long defrosting process in industrial cooling systems causes the heat given to defrost, the interruption of the cooling process causes the ambient air and products to heat up. In the second system with a hydrophilic coating, it was observed that the blowing temperature during defrosting was lower compared to the first system.

\section{ACKNOWLEDGEMENTS}

We would like to thank Nurdil Teknik Cooling Inc. for its contributions to this work.

\section{CONFLICTS OF INTEREST}

No conflict of interest was declared by the authors. 


\section{REFERENCES}

[1] Hoshino, K., Oota, Y., Hattori, N., Takemoto, M., Tanaka, T., "Developments and future trends, in: Aluminum Products with Improved Surface Functions", Kobelco Technology, 26: 63-69, (2005).

[2] Min, J., Webb, R., Bemisderfer, C., "Long-Term Hydraulic Performance of Dehumidifying HeatExchangers With and Without Hydrophilic Coatings", HVAC\&R Research, 6(3): 257-272, (2000).

[3] Min, J., Wu, X., Shen, L., Gao, F., “ Hydrophilic treatment and performance evaluation of copper finned tube evaporators", Applied Thermal Engineering, 31(14-15): 2936-2942, (2011).

[4] Moallem, E., Hong, T., Cremasch1, L., Fisher, D.E., “ Effects of surface coating and water retention on frost formation in microchannel evaporators (ASHRAE RP-1589)", HVAC\&R Research, 19: 347-362, (2014).

[5] Kılınç, F., Buyruk, E., Karabulut, K., "Experimental investigation of cooling performance with graphene-based nano fluids in a vehicle radiator", Heat and Mass Transfer, 56(2): 521-530, (2020).

[6] Karabulut, K., Buyruk, E., Kılınç, F., "Experimental and numerical investigation of convection heat transfer in a circular copper tube using graphene oxide nanofluid", Journal of the Brazilian Society of Mechanical Sciences and Engineering, 42: 230, (2020).

[7] Türkan, B., Çağlayan, A., Onbaşığlu, H., "Investigation of the Effect of Pipe Properties on the Thermal Performance of Finned Tube Evaporators using $\mathrm{CO}_{2}$ Refrigerant', Proceedings of the 3rd National Plumbing Engineering Congress, 19, 22 April, İzmir, (2017).

[8] Shafaee, M., Mashouf, H., Sarmadian, A., Mohseni, S.G., "Evaporation heat transfer and pressure drop characteristics of R-600a in horizontal smooth and helically dimpled tubes", Applied Thermal Engineering, 107: 28-36, (2016).

[9] Lillo, G., Mastrullo, R., Mauro, A. W., Viscito, L., "Flow boiling of R32 in a horizontal stainless steel tube with $6.00 \mathrm{~mm}$ ID. Experiments, assessment of correlations and comparison with refrigerant R410A”, International Journal of Refrigeration, 97: 143-156, (2019).

[10] Chen, J., Li, W., "Local flow boiling heat transfer characteristics in three-dimensional enhanced tubes", International Journal of Heat and Mass Transfer, 121: 1021-1032, (2018).

[11] He, G., Liu, F., Cai, D., Jiang, J., "Experimental investigation on flow boiling heat transfer performance of a new near azeotropic refrigerant mixture R290/R32 in horizontal tubes", International Journal of Heat and Mass Transfer, 102: 561-573, (2016).

[12] Guo, S., Wu, Z., Li, W., Kukulka, D., Sundén, B., Zho, X., Simon, T., "Condensation and evaporation heat transfer characteristics in horizontal smooth, herringbone and enhanced surface EHT tubes", International Journal of Heat and Mass Transfer, 85: 281-291, (2015).

[13] Nascimento, C.R, Mariani, V.C., Coelho, L.S., "Experimental analysis of R410A flow in helically rib-roughened tubes", Thermal Science and Engineering Progress, 20: 100668, (2020).

[14] Karabulut, K., Buyruk, E., Kılınç, F., Karabulut, Ö.O., "Farklı Geometrilerden Oluşan Kanatçıklı Plakalı Isı Değiştiricileri için Isı Transferinin Üç Boyutlu Sayısal Olarak İncelenmesi”, Tesisat Mühendisliği, 137: 35-48, (2013). 
[15] Naik, H., Tiwari, S., "Thermodynamic performance analysis of an inline fin-tube heat exchanger in presence of rectangular winglet pairs", International Journal of Mechanical Sciences, 193: 106148, (2021).

[16] Bahmanabadi, A., Faegh, M., Shafi, M.B., "Experimental examination of utilizing novel radially grooved surfaces in the evaporator of a thermosyphon heat pipe", Applied Thermal Engineering, 169: 114975, (2020).

[17] Celik, S., Nsofor, E.C., "Performance analysis of a refrigerating system with a groovedtubeevaporator", Applied Thermal Engineering 73: 745-750, (2014).

[18] Koşan, M., Demirtaş, M., Aktaş, M., Dişli, E., "Performance analyses of sustainable PV/T assisted heat pump drying system", Solar Energy, 199: 657-672, (2020).

[19] Caner, M., Duman, N., Buyruk, E., Kılınç, F., "Performance Analysis of Horizontal Ground Source Heat Pump System in Sivas", Journal of Science and Technology of Dumlupinar University, 42: 4753, (2019).

[20] Aktaş, M., Koşan, M., Arslan, E., Tuncer, A.D., "Designing a novel solar-assisted heat pump system with modification of a thermal energy storage unit", Proc IMechE Part A: J Power and Energy 233(5): 588-603, (2019).

[21] Honda, H., Wang, Y., "Theoretical study of evaporation heat transfer in horizontal microfin tubes: stratified flow model", International Journal of Heat and Mass Transfer, 47(17-18): 3971-3983, (2004).

[22] Li, S., Liu, M., Hanaor, D., Gan, Y., "Dynamics of Viscous Entrapped Saturated Zones in Partially Wetted Porous Media", Transport in Porous Media, 125: 193-210, (2018).

[23] Mahmoud, M.M., Karayiannis, T.G., "Heat transfer correlation for flow boiling in small to micro tubes", International Journal of Heat and Mass Transfer, 66: 553-574, (2013).

[24] Cavallini, A., Col, D., Doretti, L., Rossetto, L., Longo, G.A., "Refrigerant vaporization inside enhanced tubes: a heat transfer model", Heat and Technology, 17(2): 222-231, (1999).

[25] Zhang, X., Yuan, X., "Heat transfer correlations for evaporation of refrigerant mixtures flowing inside horizontal microfin tubes", Energy Conversion and Management, 49(11): 3198-3204, (2008).

[26] Üreden, A., Özden, S., "How to Calculate Corporate Carbon Footprint: A Theoretical Study", Anatolian Journal of Forest Research, 4(2): 98-108, (2018).

[27] Gibbons, M.J., Di Marco, P., Robinson, A.J., "Heat flux distribution beneath evaporating hydrophilic and superhydrophobic droplets", International Journal of Heat and Mass Transfer, 148: 119093, (2020).

[28] Kim, Y., Kim, J.S, Shin, D.H., Yo,u S.M., Lee, J., "Enhanced thermal performance of a thermosyphon for waste heat recovery: microporous coating at evaporator and hydrophobic coating at condenser", Applied Thermal Engineering, 175: 115332, (2020).

[29] Rossetto, L., Diani, A., "R513A flow boiling heat transfer inside horizontal smooth tube and microfin tube", International Journal of Refrigeration, 107: 301-314, (2019).

[30] Diani, A., Campanale, M., Rossetto, L., "Experimental study on heat transfer condensation of R1234ze(E) and R134a inside a $4.0 \mathrm{~mm}$ OD horizontal microfin tube", International Journal of Heat and Mass Transfer, 126: 1316-1325, (2018). 
[31] Çoban, M.T., Turgut, O.E., "Modeling and comparison of two-phase flow boiling heat transfer equations for various refrigerants", X. Ulusal Tesisat Mühendisliği Kongresi, İzmir, 1001-1022, (2011).

\section{NOMENCLATURE}

\section{Acronyms}

COP Coefficient of performance

Bo Bond number

Fr Froude number

GWP Global warming potential

HP Compressor discharge pressure

LP Compressor suction pressure

$\mathbf{N u} \quad$ Nusselt number

$\boldsymbol{R} \boldsymbol{e}$ Reynolds number

$\boldsymbol{P r}_{\boldsymbol{l}} \quad$ Prandtl number

$\mathrm{Pr} \quad$ Pressure ratio

$\boldsymbol{R}_{32}$ Global warming potential of R-32 refrigerant fluid

$\boldsymbol{R}_{\mathbf{1 2 5}}$ Global warming potential of R-125 refrigerant fluid

$\boldsymbol{X}_{\boldsymbol{t} t} \quad$ Martinelli number

\section{Symbols}

A $\quad$ Area $\left(\mathrm{m}^{2}\right)$

D Diameter (m)

f Grooved height $(\mathrm{mm})$

$\boldsymbol{g}$ Gravity $\left(\mathrm{m} / \mathrm{s}^{2}\right)$

h Enthalpy $(\mathrm{kJ} / \mathrm{kg})$

$\boldsymbol{h}_{\mathbf{1}} \quad$ Enthalpy of refrigerant compressor inlet $(\mathrm{kJ} / \mathrm{kg})$

$\boldsymbol{h}_{2}$ Enthalpy of refrigerant compressor outlet $(\mathrm{kJ} / \mathrm{kg})$

$\boldsymbol{h}_{\mathbf{4}} \quad$ Enthalpy of refrigerant evaporator inlet $(\mathrm{kJ} / \mathrm{kg})$

$\boldsymbol{h}$ Heat transfer coefficient $\left(\mathrm{W} / \mathrm{m}^{2} \mathrm{~K}\right)$

$\boldsymbol{h}_{c v} \quad$ Evaporation heat transfer coefficient $\left(\mathrm{W} / \mathrm{m}^{2} \mathrm{~K}\right)$

$\boldsymbol{h}_{\boldsymbol{n} \boldsymbol{b}} \quad$ Nucleate heat transfer coefficient $\left(\mathrm{W} / \mathrm{m}^{2} \mathrm{~K}\right)$

$\boldsymbol{h}_{\boldsymbol{t} p} \quad$ Two-phase flow heat transfer coefficient $\left(\mathrm{W} / \mathrm{m}^{2} \mathrm{~K}\right)$

$\boldsymbol{k} \quad$ Thermal conductivity coefficient $(\mathrm{W} / \mathrm{mK})$

$\boldsymbol{l} \quad$ Serpantine length of evaporator condition (m)

$\dot{\boldsymbol{m}} \quad$ Refrigerant mass flow rate $(\mathrm{kg} / \mathrm{s})$

$\Delta \mathbf{p} \quad$ Air side pressure drop across an evaporator $(\mathrm{Pa})$

$\dot{\boldsymbol{Q}} \quad$ Evaporator capacity $(\mathrm{kW})$

$\boldsymbol{T} \quad$ Low temperature source $\left({ }^{\circ} \mathrm{C}\right)$

$\Delta \boldsymbol{T}_{l m} \quad$ Logarithmic mean temperature difference $\left({ }^{\circ} \mathrm{C}\right)$

$\boldsymbol{T}_{\boldsymbol{R} 290}$ Total refrigerant mass $(\mathrm{kg})$

$\boldsymbol{t}_{\text {year }}$ Percent refrigerant added to the system during the year (\%)

U Total heat transfer coefficient $\left(\mathrm{W} / \mathrm{m}^{2} \mathrm{~K}\right)$

$\boldsymbol{V} \quad$ Volumetric flow rate of air $\left(\mathrm{m}^{3} / \mathrm{s}\right)$

$\dot{W} \quad$ Compressor power input $(\mathrm{kW})$

$\Gamma \quad$ Mass flux $\left(\mathrm{kg} / \mathrm{m}^{2} \mathrm{~s}\right)$

$\boldsymbol{\mu}$ Dynamic viscosity $(\mathrm{kg} / \mathrm{ms})$

\section{Subscripts}

$\begin{array}{ll}\boldsymbol{a} & \text { Air } \\ \boldsymbol{c} & \text { Compressor }\end{array}$ 


$\begin{array}{ll}\boldsymbol{e} & \text { Evaporator } \\ \boldsymbol{f} & \text { Fan } \\ \boldsymbol{H} & \text { High } \\ \boldsymbol{i} & \text { Inlet } \\ \boldsymbol{l} & \text { Liquid } \\ \boldsymbol{L} & \text { Low } \\ \boldsymbol{M} & \text { Molarity } \\ \boldsymbol{n} & \text { Number of grooved } \\ \boldsymbol{o} & \text { Outlet } \\ \boldsymbol{r} & \text { Refrigerant } \\ \boldsymbol{s} & \text { Surface } \\ \boldsymbol{t r} & \text { Carnot efficiency } \\ \boldsymbol{v} & \text { Vapor } \\ \boldsymbol{X} & \text { Dryness degree } \\ \boldsymbol{\eta} & \text { Second-law efficiency } \\ \boldsymbol{\eta} & \text { Efficiency } \\ \boldsymbol{\theta} & \text { Grooved apex angle } \\ \boldsymbol{\beta} & \text { Grooved angle }\end{array}$

